удК 616.311-089.5-06+616.831:616.152.21]-053.2-07-084

DOI 10.11603/2311-9624.2019.4.10882

(C). І. Коваль, П. Б. Коваль

Національний медичний університет імені О. О. Богомольця, м. Київ

e-mail: okoval78@ukr.net

\title{
Церебральна оксиметрія як метод моніторингу кисневого насичення головного мозку в дітей віком 7-12 років при санації ротової порожнини під загальним знеболюванням в амбулаторних умовах
}

\section{ІНФОРМАЦІЯ}

Надійшла до редакції/Received: 09.11.2019 p.

Ключові слова: церебральна оксиметрія; $\mathrm{SpO}_{2} ; \mathrm{rSO}_{2}$; загальне знеболювання.
АНОТАЦІЯ

Резюме. В статті представлено результати оцінки кисневого статусу головного мозку в період санації ротової порожнини в умовах загального знеболювання.

Мета дослідження - обгрунтувати необхідність обмеження в часі у дітей віком 7-12 років з метою запобігання виникнення когнітивних дисфункцій головного мозку на тлі гіпоксичних уражень.

Матеріали і методи. Оцінку кисневого статусу головного мозку в період санації ротової порожнини в умовах загального знеболювання (без інтубації) проведено 31 дитині віком 7-12 років на базі Стоматологічного медичного центра при Національному медичному університеті імені О. О. Богомольця за допомогою методу нейромоніторингу - церебральної оксиметрії (апарат для моніторингу газу крові: 4-канальний регіональний оксиметр з технікою EQUANOXTM, технікою безпровідного зв'язку Bluetooth та RS-232 (модель 7600) (свідоцтво про державну реєстрацію № 12580/2013. Виробник: Nonin Medical, Inc., USA).

Результати досліджень та їх обговорення. Зниження показника $\mathrm{rSO}_{2}$ відбувається 340 хв. Мінімально допустиме значення $\mathrm{rSO}_{2}=60,44 \%$. Тотожне мінімальному значенню $\mathrm{rSO}_{2}(60,44 \pm 0,46) \%$ знаходиться між 55 та 56 хв. Під час проведення стоматологічного втручання під загальним знеболюванням відмічено ускладнення у вигляді ларингоспазму в 12,9 \%. Серед дітей, які мали ускладнення у вигляді ларингоспазму в 75 \% у анамнезі відмічали менш ніж 2 тижні після повного одужання з приводу гострих респіраторних захворювань (ГРЗ). Тому ми вважали, що значну роль у виникненні ларингоспазму відіграють запальні процеси слизової оболонки дихальних шляхів на тлі вікових особливостей їх анатомічної будови. При ларингоспазмі $\mathrm{rSO}_{2}$ становить $(70,69 \pm 6,47) \%$, що $\downarrow 6,42 \%$ відносно середнього показника $\mathrm{rSO}_{2}$ відповідної вікової групи $\left(\mathrm{rSO}_{2}=(75,54 \pm 2,27) \%\right)$. Зниження показника $\mathrm{rSO}_{2}$ відмічається з 11 хв до 28 хв $\left(\leq 20\right.$ хв) на 8,26 \% $\left(\mathrm{rSO}_{2}=(64,85 \pm 3,51) \%\right.$. Максимальне зниження відбулося на 17 хв $\left(\mathrm{rSO}_{2}=(60,25 \pm 4,08) \%\right.$, що склало $14,77 \%$ від загального значення ( $<<0,05)$ та 7,09 \% від показника $\mathrm{rSO}_{2}$ безпосередньо при ларингоспазмі. Для доведення залежності можливості виникнення ускладнення від терміну повної реабілітації після запальних процесів дихальних шляхів ми провели аналіз показників $\mathrm{rSO}_{2}$ у 2-х групах. Отже, наявність в анамнезі гострих респіраторних захворювань у дітей віком 7-12 років обмежує надання 
стоматологічної допомоги в амбулаторних умовах під загальним знеболюванням.

Висновки. Метод церебральної оксиметрії є інформатиним методом нейромоніторингу при проведенні санації ротової порожнини в умовах загального знеболювання. Стоматологічну санацію ротової порожнини в амбулаторних умовах під загальним знеболю-

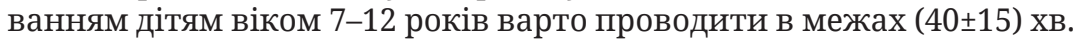
Протипоказанням для планового проведення санації ротової порожнини під загальним знеболюванням в амбулаторних умовах у дітей віком 7-12 років є гострі респіраторні захворювання в анамнезі менш ніж за 2 тижні. При наявності в анамнезі гострих респіраторних захворювань менш ніж за 2 тижні та гострою стоматологічною потребою, надання швидкої допомоги під загальним знеболюванням в амбулаторних умовах у дітей віком 7-12 років можливо в межах 10 хв.

Вступ. За даними літератури, з метою забезпечення загального знеболювання при оперативних втручаннях, інгаляційні та внутрішньовенні анестетики використовують понад 160 років.

На сьогодні значну кількість наукових досліджень присвячено вивченню негативного впливу загального знеболювання на когнітивні функції у пацієнтів різного віку [1-5]. Сукупність багатьох чинників, таких, як: стрес перед оперативним втручанням, супутня патологія, ускладнення в процесі проведення операції, початкові дані когнітивних функцій, вік, анатомо-фізіологічні особливості дихальної, нервової та судинної систем можуть зумовлювати виникнення церебральних ускладнень в операційний та післяопераційний періоди [6-11].

Одне із перших місць у статистці анестезіологічних ускладнень, які призводять до функціональних порушень головного мозку, посідають гіпоксичні ураження [12].

Тому для безпеки пацієнта під час санації ротової порожнини в умовах загального знеболювання $€$ вкрай необхідним моніторинг головного мозку [13, 14]. Застосування даного методу дозволить об'єктивно оцінити насичення киснем церебральних судин під час стоматологічної санації в умовах загального знеболювання та визначити безпечний проміжок часу проведення санації ротової порожнини без ризику виникнення функціональних порушень головного мозку на тлі його гіпоксії [15-17].

Метою дослідження було обгрунтувати тривалість проведення санації ротової порожнини в амбулаторних умовах під загальним знеболюванням (без інтубації) у дітей віком
7-12 років для запобігання виникнення когнітивних дисфункцій головного мозку на фоні гіпоксичних уражень.

Матеріали і методи. Оцінку кисневого статусу головного мозку в період санації ротової порожнини в умовах загального знеболювання (без інтубації) проведено 31 дитині віком 7-12 років на базі Стоматологічного медичного центра при Національному медичному університеті імені О. О. Богомольця за допомогою методу нейромоніторингу - церебральної оксиметрії (апарат для моніторингу газу крові: 4-х канальний регіональний оксиметр 3 технікою EQUANOXTM, технікою безпровідного зв'язку Bluetooth та RS-232 (модель 7600) (свідоцтво про державну реєстрацію № 12580/2013. Виробник: Nonin Medical, Inc., USA).

Згідно 3 класифікацією темпераменту (Томас та Чесс, 1997) до даної вікової групи дітей увійшли: діти 3 «легким» темпераментом - 7 осіб; діти 3 «складним» темпераментом - 13; діти 3 темпераментом "довго розігрівається» -11 осіб.

Для прогнозу когнітивних змін на фоні гіпоксичних порушень головного мозку ми користувались результатами досліджень J. Meixensberger et. al., 1998 [18]:

Результати досліджень та їх обговорення. Динаміка показників церебральної оксиметрії на всіх етапах оперативного втручання у дітей віком 7-12 років залежно від темпераменту представлена в таблиці 1.

Як видно із таблиці 1, показники церебральної оксиметрії до індукції у дітей 3 «легким» та «тяжким» темпераментами достовірно нижчі відносно загального середнього значення i становлять $(67,58 \pm 1,06)$ та $(68,53 \pm 1,71)$ \% відповідно ( $\leq \leq 0,01)$. Дану ситуацію можна пояснити 
таблищя 1. Показники $\mathrm{rSO}_{2}$ у дітей 7-12 років на усіх етапах санації ротової порожнини під загальним знеболюванням в амбулаторних умовах (без інтубації) залежно від виду темпераменту

\begin{tabular}{|c|c|c|c|c|c|}
\hline \multirow[b]{2}{*}{$\begin{array}{c}\text { Вид } \\
\text { темпераменту }\end{array}$} & \multicolumn{5}{|c|}{ Етап лікування } \\
\hline & $\begin{array}{c}\text { до індукції } \\
\text { (\%) }\end{array}$ & $\begin{array}{l}\text { індукція } \\
\text { (\%) }\end{array}$ & $\begin{array}{c}\text { лікування } \\
\text { (\%) }\end{array}$ & $\begin{array}{c}\text { після ліку- } \\
\text { вання (\%) }\end{array}$ & $\begin{array}{c}\text { загальне } \\
\text { значення (\%) }\end{array}$ \\
\hline $\begin{array}{l}\text { «Легкий» } \\
(\mathrm{n}=7)\end{array}$ & $67,58 \pm 1,06^{*}$ & $74,98 \pm 1,07$ & $76,47 \pm 0,81$ & $76,4 \pm 1,11$ & $73,99 \pm 0,73$ \\
\hline $\begin{array}{l}\text { «Складний» } \\
(\mathrm{n}=13)\end{array}$ & $68,53 \pm 1,71^{*}$ & $72,3 \pm 1,49$ & $74,38 \pm 2,22$ & $75,15 \pm 1,5$ & $72,59 \pm 0,79$ \\
\hline $\begin{array}{l}\text { «Довго розігрівається" } \\
(\mathrm{n}=11)\end{array}$ & $70,81 \pm 1,72$ & $76,15 \pm 2,45$ & $76,15 \pm 0,58$ & $77,64 \pm 0,58$ & $75,36 \pm 0,94$ \\
\hline $\begin{array}{l}\text { Середнє значення } \\
(\mathrm{n}=31)\end{array}$ & $69,19 \pm 1,99$ & $74,52 \pm 2,3$ & $75,66 \pm 2,27$ & $76,31 \pm 1,45$ & $73,89 \pm 1,47$ \\
\hline
\end{tabular}

Примітка. * - достовірність значення показників відносно загального середнього значення $(\mathrm{p} \leq 0,01)$.

психофізіологічними особливостями дітей даного віку.

Достовірної різниці показників церебральної оксиметрії у дітей під час проведення санації ротової порожнини в умовах загального знеболювання (без інтубації) залежно від темпераменту не відмічено.
Динаміка показників церебральної оксиметрії у часовому проміжку безпосередньо при стоматологічному лікуванні представлені на рисунку 1.

Як видно з рисунка 1, зниження показника $\mathrm{rSO}_{2}$ відбувається з 40-ї хв. Мінімально допустиме значення $\mathrm{rSO}_{2}$ склало 60,44 \% (табл.

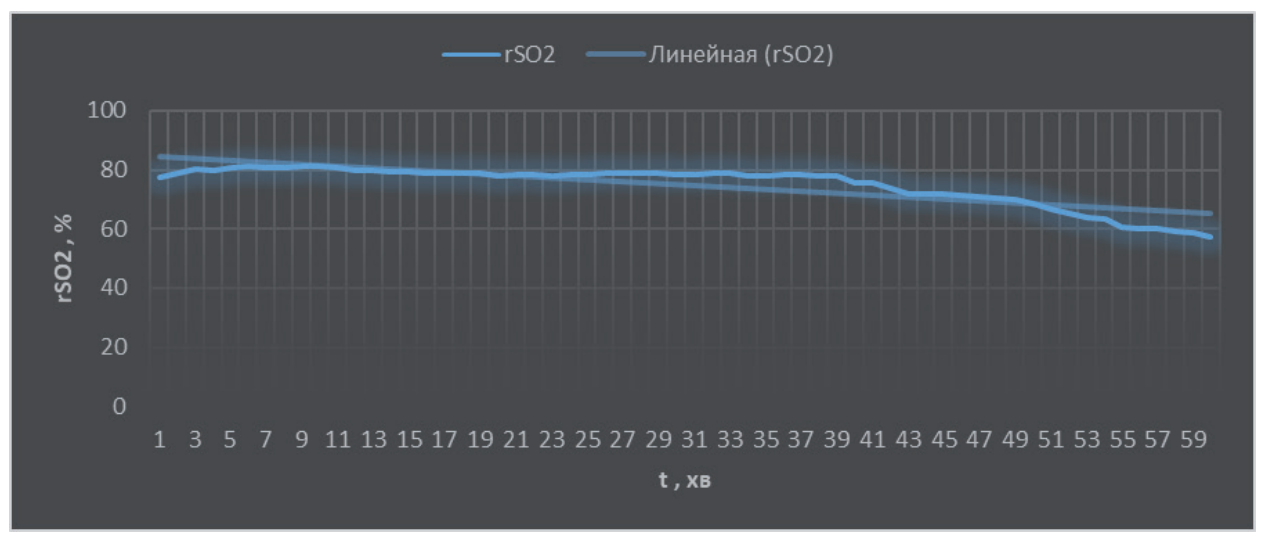

Puc. 1. Показники $\mathrm{rSO}_{2}$ у дітей віком 7-12 років у період санації ротової порожнини під загальним знеболюванням в амбулаторних умовах.

2). Тотожне мінімальному значенню $\mathrm{rSO}_{2}$ $(60,44 \pm 0,46) \%$ знаходиться між 55 та 56 хв.

Максимельне значення $\mathrm{rSO}_{2}(81,12 \pm 1,02) \%$ відмічено на 6 хв та не виходить за межі границь норми, яка становить 90,64 \% (табл. 2).
Враховуючи лінійне зниження насичення киснем церебральних судин головного мозку та межі мінімально допустимого значення, можна стверджувати, що стоматологічну санацію ротової порожнини в умовах загально-

Таблиця 2. Min- та Мax-показники допустимих норм показників $\mathrm{rSO}_{2}$ для дітей віком 7-12 років різного темпераменту

\begin{tabular}{|c|c|c|c|}
\hline \multirow{2}{*}{ Темперамент } & \multicolumn{3}{|c|}{ Середнє значення } \\
\cline { 2 - 4 } & легкий & складний & $\mathrm{n}=11$ \\
\hline $\mathrm{n}=31$ & $\mathrm{n}=7$ & $\mathrm{Max}=89,26 \%$ & $\mathrm{Max}=91,38 \%$ \\
\hline $\mathrm{Max}=90,64 \%$ & $\mathrm{Max}=92,09 \%$ & $74,38 \%$ & $76,15 \%$ \\
$(20 \%=15,1 \%)$ & $76,74 \%$ & $(20 \%=14,88 \%)$ & $(20 \%=15,23 \%)$ \\
\hline Min=60,44 \% & $(20 \%=15,35 \%)$ & $\operatorname{Min}=59,5 \%$ & $\operatorname{Min}=60,92 \%$ \\
\hline
\end{tabular}

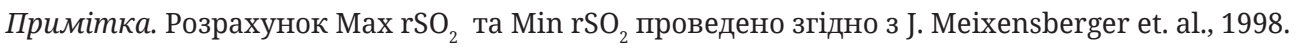


го знеболювання (без інтубації) з метою запобігання виникнення когнітивних порушень на тлі гіпоксичних уражень дітям віком від 7-ми до 12-ти років варто проводити в межах $(40 \pm 15)$ хв.

Під час проведення стоматологічного втручання в умовах загального знеболювання (без інтубації) встановлено ускладнення у вигляді ларингоспазму в 12,9 \% дітей.

Серед дітей, які мали ускладнення у вигляді ларингоспазму в 75 \% у анамнезі відмічали менш ніж 2 тижні після повного одужання 3 приводу гострих респіраторних захворювань (ГРЗ). Тому ми вважали, що значну роль у виникненні ларингоспазму відіграють запальні процеси слизової оболонки дихальних шляхів на тлі вікових особливостей їх анатомічної будови.

Динаміку показників церебральної оксиметрії при ларингоспазмах у процесі стоматологічної санації в умовах загального знеболювання (без інтубаціі) представлено на рисунку 2.

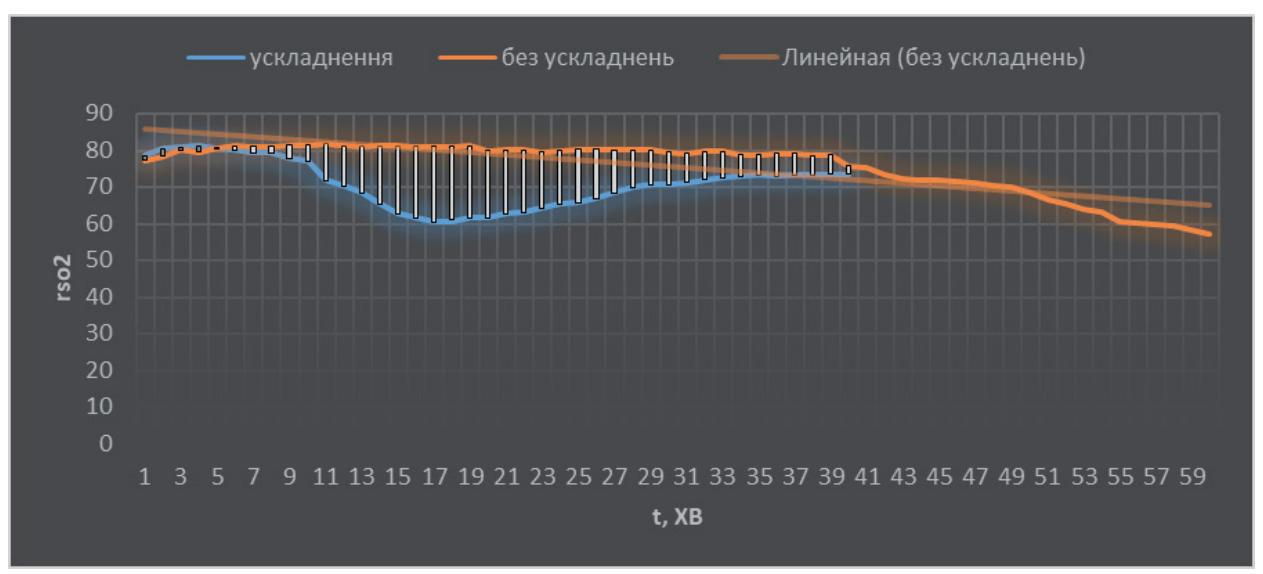

Puc. 2. Динаміка показника $\mathrm{rSO}_{2}$ при ускладненнях під час проведення санації ротової порожнини під загальним знеболюванням у дітей віком 7-12 років.

При ларингоспазмі $\mathrm{rSO}_{2}$ становить $(70,69 \pm 6,47) \%$, що $\downarrow 6,42 \%$ відносно середнього показника $\mathrm{rSO}_{2}$ відповідної вікової групи $\left(\mathrm{rSO}_{2}=(75,54 \pm 2,27) \%\right)$.

Зниження показника $\mathrm{rSO}_{2}$ при ларингоспазмі відмічається з 11 хв до 28 хв ( $\leq 20 \mathrm{xв)} \mathrm{на}$ $8,26 \%\left(\mathrm{rSO}_{2}=(64,85 \pm 3,51) \%\right)$.

Максимальне зниження відбулося на 17 хв $\left(\mathrm{rSO}_{2}=(60,25 \pm 4,08) \%\right.$, що склало $14,77 \%$ від загального значення $(\mathrm{p}<0,05)$ та 7,09 \% від показника $\mathrm{rSO}_{2}$ безпосередньо при ларингоспазмі.
Для доведення залежності можливості виникнення ускладнення від терміну повної реабілітації після запальних процесів дихальних шляхів ми провели аналіз показників $\mathrm{rSO}_{2}$ у 3-х групах: перша група, хворі мали ГР3 в анамнезі $\leq 2$-х тижнів, друга група - діти, які мали ГР3 в анамнезі $\geq 2$-х тижнів, але $\leq 4$-х тижнів (12,9 \%) відносно показників загальної групи дітей віком 7-12 років (третя група) (рис. 3).

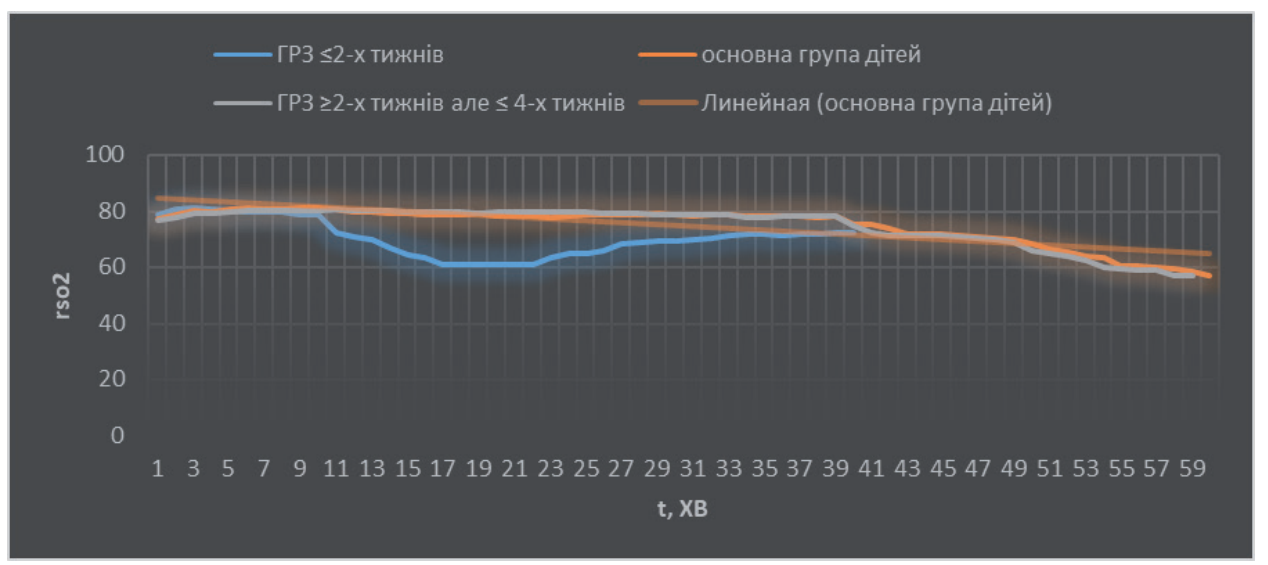

Puc. 3. Показники $\mathrm{rSO}_{2}$ у дітей віком 7-12 років, які мали в анамнезі ГР3 $\leq 2-\mathrm{x}$ тижнів (перша), та ГР3 $\geq 2$-х тижнів, але $\leq 4$-х тижнів (друга) та їх кореляція відносно основної групи дітей (третя). 
$\mathrm{rSO}_{2}$ першої групи - $(70,42 \pm 6,45) \%$. Зниження $\mathrm{rSO}_{2}$ відмічено 311 хв до 38 хв $(>20 \mathrm{xв})$ на $5,29 \%\left(\mathrm{rSO}_{2}=(66,69 \pm 4,22) \%\right)$.

Максимальне зниження $\mathrm{rSO}_{2}$ відбулося на 29 хв $(60 \pm 7,0) \%$ (р<0,05), що склало $14,79 \%$ від середнього значення у даній групі та 10,03 \% від показника $\mathrm{rSO}_{2}$ безпосередньо при ларингоспазмі.

У другій групі дітей достовірної відмінності показників $\mathrm{rSO}_{2}$, порівняно 3 третьою групою, не встановлено. $\mathrm{rSO}_{2}$ становить $(74,92 \pm 7,16) \%$ та $(75,54 \pm 2,27) \%$ відповідно.

Отже, наявність в анамнезі гострих респіраторних захворювань у дітей віком 7-12 років обмежує надання стоматологічної допомоги в амбулаторних умовах під загальним знеболюванням. За ургентним станом вищезазначена допомога може бути надана з обмеженням в часі $(\leq 10 \mathrm{xB})$.

Висновки. 1. Метод церебральної оксиметрії $€$ інформативним методом нейромоніторингу при проведенні санації ротової порожнини в умовах загального знеболювання.

2. Стоматологічну санацію ротової порожнини в амбулаторних умовах під загальним знеболюванням (без інтубації) дітям віком 7-12 років варто проводити в межах $(40 \pm 15)$ хв.
3. Протипоказанням для планового проведення санації ротової порожнини під загальним знеболюванням (без інтубації) в амбулаторних умовах у дітей віком 7-12 років є гострі респіраторні захворювання в анамнезі менш ніж за 2 тижні.

4. При наявності в анамнезі гострих респіраторних захворювань менш ніж за 2 тижні та гострою стоматологічною потребою, надання швидкої допомоги в умовах загального знеболювання (без інтубації) у дітей віком 7-12 років можливо в межах 10 хв.

Перспективи подальших досліджень. Вивчити динаміку показників церебральної оксиметрії під час проведення різних стоматологічних маніпуляцій на амбулаторному стоматологічному прийомі у дітей віком 7-12 років. Встановити безпечний проміжок часу для проведення стоматологічних маніпуляцій різного характеру в дітей віком 7-12 років на стоматологічному амбулаторному прийомі 3 урахуванням типу темпераменту та виду фобій. Провести аналіз якості надання стоматологічної допомоги в різних умовах. Створити алгоритм лікування зубів у дітей віком 7-12 років під загальним знеболюванням (без інтубації) в амбулаторних умовах.

\section{со. И. Коваль, П. Б. Коваль}

Национальный медицинский университет имени А. А. Богомольца, г. Киев

\section{Церебральная оксиметрия как метод мониторинга кислородного насыщения головного мозга у детей в возрасте 7-12 лет при санации полости рта под общим обезболиванием в амбулаторных условиях}

Резюме. В статье представлены результаты оценки кислородного статуса головного мозга в период санации полости рта в условиях общего обезболивания.

Цель исследования - обосновать необходимость ограничения во времени у детей в возрасте 7-12 лет с целью предотвращения возникновения когнитивных дисфункций головного мозга на фоне гипоксических поражений.

Материали и методы. Оценка кислородного статуса головного мозга в период санации полости рта в условиях общего обезболивания (без интубации) проведена 31 ребенку в возрасте 7-12 лет на базе Стоматологического медицинского центра при Национальном медицинском университете имени А. А. Богомольца при помощи метода нейромониторинга - церебральной оксиметрии (аппарат для мониторинга газа крови: 4-канальный региональный оксиметр с техникой EQUANOXTM, техникой беспроводной связи Bluetooth и RS-232 (модель 7600) (свидетельство о государственной регистрации № 12580/2013. Производитель: Nonin Medical, Inc., USA).

Результаты исследований и их обсуждение. Снижение показателя $\mathrm{rSO}_{2}$ происходит с 40 мин. Минимально допустимое значение $\mathrm{rSO}_{2}=60,44$ \%. Соответственно минимальному значению $\mathrm{rSO}_{2}$ $(60,44 \pm 0,46) \%$ находится между 55 та 56 мин. Во время проведения стоматологического лечения под общим обезболиванием отмечено осложнения в виде ларингоспазма у 12,9%. Среди детей, которые имели осложнения в виде ларингоспазма, у 75 \% в анамнезе отмечали менее чем 2 недели после полного выздоровления по поводу острых респираторных заболеваний (ОР3). Поэтому мы считали, 
что значимую роль в возникновении ларингоспазма играют воспалительные процесы слизистой оболочки дыхательных путей на фоне возрастных особенностей их анатомического строения. При ларингоспазме $\mathrm{rSO}_{2}$ составляет $(70,69 \pm 6,47) \%$, что $\downarrow 6,42 \%$ по отношению к середнему показателю $\mathrm{rSO}_{2}$ соответствующей возрастной группы $\left(\mathrm{rSO}_{2}=(75,54 \pm 2,27) \%\right)$. Снижение показателя $\mathrm{rSO}_{2}$ отмечается с 11 мин по 28 мин ( $\leq 20$ мин) на 8,26 \% ( $\left.\mathrm{rSO}_{2}=(64,85 \pm 3,51) \%\right)$. Максимальное снижение произошло на 17 мин $\left(\mathrm{rSO}_{2}=(60,25 \pm 4,08) \%\right)$, что составило $14,77 \%$ от общего значения (p<0,05) и 7,09 \% от показателя $\mathrm{rSO}_{2}$ непосредственно при ларингоспазме. Для подтверждения зависимости возможности возникновения отклонения от вемени полной реабилитации после воспалительных процессов дыхательных путей нами проведен анализ показателей $\mathrm{rSO}_{2}$ у 2-х группах. Итак, наличие в анамнезе острых респираторных заболеваний у детей в возрасте 7-12 лет ограничивает оказание стоматологической помощи в амбулаторных условиях под общим обезболиванием.

Выводы. Метод церебральной оксиметрии есть информативным методом нейромониторинга при поведении санации полости рта в условиях общего обезболивания. Стоматологическую санацию полости рта в амбулаторных условиях под общим обезболиванием детям в возрасте 7-12 лет стоит проводить в границах $(40 \pm 15)$ мин. Противопоказанием к плановому проведению санации полости рта под общим обезболиванием в амбулаторных услвиях у детей в возрасте 7-12 лет есть острые респираторные заболевания в анамнезе менее чем 2 недели. При наличии в анамнезе острых респираторных заболеваний менее чем 2 недели и острой стоматологической необходимостью, оказание скорой помощи под общим обезболиванием в амбулаторных услвиях у детей в возрасте 7-12 лет возможно в границах 10 мин.

Ключевые слова: церебральная оксиметрия; $\mathrm{SpO}_{2} ; \mathrm{rSO}_{2}$; общее обезболивание.

\author{
(C). I. Koval, P. B. Koval
}

O. Bohomolets National Medical University, Kyiv

\title{
Cerebral oximetry as a method for monitoring oxygen saturation of the brain in children aged 7-12 years with rehabilitation of the oral cavity under general anesthesia on an outpatient basis
}

Summary. The article presents the results of the assessment of the oxygen status of the brain during the period of rehabilitation of the oral cavity in conditions of general anesthesia.

The aim of the study - the necessity of a time limit in children aged 7-12 years is substantiated in order to prevent the occurrence of cognitive dysfunctions of the brain against the background of hypoxic lesions.

Materials and Methods. Assessment of the oxygen status of the brain during the rehabilitation of the oral cavity in conditions of general anesthesia (without intubation) was conducted on 31 children aged 7-12 years at the Dental Medical Center at the National Medical University named after O. Bohomolets using neuromonitoring method - cerebral oximetry (blood gas monitoring device: 4-channel regional oximeter with EQUANOXTM technique, Bluetooth wireless technology and RS-232 (model 7600) (State Registration Certificate No. 12580/2013. Producer : Nonin Medical, Inc., USA).

Results and Discussion. The decrease in $\mathrm{rSO}_{2}$ occurs with $40 \mathrm{~min}$. The minimum value of $\mathrm{rSO}_{2}=60.44 \%$. Identical to the minimum $\mathrm{rSO}_{2}$ value $(60.44 \pm 0.46) \%$ is between 55 and $56 \mathrm{~min}$. During the dental intervention under general anesthesia, complications in the form of laryngospasm were noted in $12.9 \%$. Among children who had a history of laryngospasm complications, $75 \%$ had a history of less than 2 weeks after complete recovery for acute respiratory disease (ARD). Therefore, we considered that inflammatory processes of the respiratory mucosa play a significant role in the occurrence of laryngospasm against the background of agerelated features of their anatomical structure. When laryngospasm $\mathrm{rSO}_{2}$ is $(70.69 \pm 6.47) \%$, which is $6.42 \%$ relative to the mean $\mathrm{rSO}_{2}$ of the respective age group $\left(\mathrm{rSO}_{2}=(75.54 \pm 2.27) \%\right.$. The decrease in $\mathrm{rSO}_{2}$ is observed from 11 minutes. To $28 \mathrm{~min} .(\leq 20 \mathrm{~min})$ is $8.26 \%\left(\mathrm{rSO}_{2}=(64.85 \pm 3.51) \%\right.$. The maximum decrease occurred in 17 minutes $\left(\mathrm{rSO}_{2}=(60.25 \pm 4.08) \%\right.$, accounting for $14.77 \%$ of the total value $(\mathrm{p}<0.05)$ and $7.09 \%$ of the $\mathrm{rSO}_{2}$ index directly for laryngospasm. Therefore, the presence of a history of acute respiratory illness in children aged 7-12 years limits the provision of dental care in an outpatient setting under general anesthesia.

Conclusions. The method of cerebral oximetry is an informative method of neuromonitoring when the behavior of oral sanitation under conditions of general anesthesia is performed. Dental rehabilitation of the oral cavity on an outpatient basis under general anesthesia for children aged 7-12 years should be carried out within $(40 \pm 15) \mathrm{min}$. A contraindication to scheduled oral sanitation under general anesthesia in outpatient settings for children aged 7-12 years has acute respiratory infections in the anamnesis of less than 2 weeks. If there is a history of acute respiratory infections in less than 2 weeks and an acute 
dental need, emergency care under general anesthesia in outpatient settings for children aged 7-12 years is possible within 10 min.

Key words: cerebral oximetry; $\mathrm{SpO}_{2} ; \mathrm{rSO}_{2}$; general anesthesia.

\section{СПИСОК ЛІТЕРАТУРИ}

1. Эпидемиология послеоперационных когнитивных нарушений / Р. В. Большедворов, В. В. Кичин, С. А. Федоров, В. В. Лихванцев // Анестезиология и реанимация. - 2009. - № 3. - С. 20-24.

2. Нікішова I. М. Чутливість когнітивних функцій до тягаря хвороби малих судин головного мозку / I. М. Нікішова, В. М. Міщенко, Д. О. Кутіков // Український вісник психоневрології. - 2019. - Т. 27, вип. 1(98). - C. 20-26.

3. Яхно Н. Н. Нарушение когнитивных функций. Неврология : национальное руководство / Н. Н. Яхно, В. В. Захаров. - 2010. - Гл. 26. - С. 532-547.

4. Bartels M. Anesthesia and cognitive performance in children: no evidence for a causal relationship / M. Bartels, R. R. Althoff, D. I. Boomsma // Twin Res. Hum. Genet. - 2009. - Vol. 12(03). - P. 246-253.

5. Rasmussen L. Cognitive dysfunction and other long-term complications of surgery and anesthesia / L. Rasmussen, J. Stygall, S. Newman // Miller's Anesthesia. - 2010. - Vol. 7. - P. 2805-2819.

6. Князев А. В. Церебральные и метаболические нарушения при оперативных вмешательствах под общим обезболиванием у детей : автореф. дисс. на соискание уч. степени канд. наук / А. В. Князев. - М. : Московский областной научно-исследовательский клинический институт им. М. Ф. Владимирского, 2006. -20 с.

7. Влияние пропофола на гиппокамп развивающегося мозга / М. А. Лобов, А. А. Древаль, А. М. Овезов [и др.] // Эксперементальная неврология. - 2013. T. 7, № 3. - C. 42-46.

8. Backman M. E. Iatrogenic effects of general anesthesia in children: considerations in treating large congenital nevocytic nevi / M. E. Backman, A. W. Kopf // J. Dermatol. Surg. Oncol. - 1986. - Vol. 12(4). - P. 363-367.

9. Burkhart C. S. Can postoperative cognitive dysfunction be avosded? / C. S. Burkhart, L. A. Steiner // Hosp. Pract. (1995). - 2012. - Vol. 40(1). - P. 214-223.

\section{REFERENCES}

1. Bolshedvorov, R.V., Kichin, V.V., Fedorov, S.A., \& Likhvantsev, V.V. (2009). Epidemiologiya posleoperatsionnykh kognityvnykh narusheniy [Epidemiology of postoperative cognitive impairment]. Anesteziologiya $i$ reanimatsiya - Anesthesiology and Resuscitation, 3, 2024 [in Russian].

2. Nikishova, I.M., Mishchenko, V.M., \& Kutikov, D.O. (2019). Chutlyvist kohnityvnykh funktsii do tiaharia khvoroby malykh sudyn holovnoho mozku [Sensitivity of cognitive functions to the burden of disease of small vessels of the brain]. Ukrainskyi visnyk psykhonevrolohii - Ukrainian Journal of Psychoneurology, 27, 1 (98), 20-26 [in Ukrainian].
10. Kalkman C. J. Behavior and development in children and age all the time of first anesthetic exposure / C. J. Kalkman, L. Peelen, K. G. Moons // Anesthesiology. 2009. - Vol. 110. - P. 805-812.

11. Lobov M. Perioperative prevention of early cognitive dysfunction in children / M. Lobov, A. Knyazev, A. Ovezov // Intensive Care Medicine. - 2010. Vol. 36 (2). - P. 276.

12. Давыдова Н. С. Возможные критерии прогноза нарушений мозгового кровообращения при анестезии / Н. С. Давыдова // Вестник интенсивной терапии. - 2004. - Vol. 5. - P. 232-234.

13. Аксельрод Б. А. Мониторинг тканевой оксигенации: новая волна в палитре анестезиолога / Б. А. Аксельрод // Вестник интенсивной терапии. 2012. - Vol. 1. - P. 8-14.

14. Лубин А. Ю. Церебральная оксиметрия / А. Ю. Лубин, А. В. Шмигельский // Анестезия и реаниматология. - 1996. - № 2. - С. 85-90.

15. Mchedlishvili G. I. Arterial behavior and blood circulation in the brain / G. I. Mchedlishvili. N.-Y., 1998. - P. 56-57.

16. New noninvasive methods for assessing brain oxygenation and haemodynamics / E. O. Reynolds, J. S. Wyatt, D. Azzopardi [et al.] // Br. Med. Bull. - 1988. Vol. 44 (4). - P. 1052-1075.

17. Cerebral oxygenation is associated with neurodevelopmental outcome of preterm children at age 2-3 years / E. A. Verhagen, K. N. Van Braeckel, C. N. van der Veere [et al.] // Dev. Med. Child. Neurol. 2015. - Vol. 57 (5). - P. 449-455.

18. Monitoring of cerebral oxygenation by near infrared spectroscopy vs brain tissue PO2 and cerebral perfusion pressure following severe head injury: Proceedings from International Cerebral Hemodynamic Symposium / J. Heixensberger, J. T. A. Dings, B. Hanelbeck, K. Roosen // Stroke. - 1995. - Vol. 26 (4). - P. 721-721.

3. Yachno, N.N., \& Zakharov, V.V. (2010). Kognitivnye narusheniya [Cognitive impairment. Neurology: National Leadership] [in Russian].

4. Bartels, M., Althoff, R.R., \& Boomsma, D.I. (2009). Anesthesia and cognitive performance in children: no evidence for a causal relationship. Twin Res. Hum. Genet., 12 (03), 246-253. doi:10.1375/twin.12.3.246.

5. Rasmussen, L., Stygall, J., \& Newman, S. (2010). Cognitive dysfunction and other long-term complications of surgery and anesthesia. Miller's Anesthesia, 7, 28052819.

6. Knyazev, A.V. (2006). Tserebralnye i metabolicheskye narusheniya $\mathrm{v}$ khirurgii pod obshchym obezbolivaniem 
$\mathrm{u}$ detey [Cerebral and metabolic disorders in surgery under general anesthesia in children]. Extended Abstract of Candidate's thesis. Kyiv [in Russian].

7. Lobov, M.A., \& Dreval, A.A. (2013). Vliyaniye propofola na gippokamp razvivayushchegosya mozga [The effect of propofol on the hippocampus of the developing brain]. Eksperimentalnaya nevrologiya - Experimental Neurology, 7 (3), 42-46 [in Russian].

8. Backman, M.E., \& Kopf, A.W. (1986). Iatrogenic effects of general anesthesia in children: considerations in treating large congenital nevocytic nevi. J. Dermatol. Surg. Oncol., 12 (4), 363-367.

9. Burkhart, C.S. (2012). Can postoperative cognitive dysfunction be avoided? Hosp. Pract. (Minneap), 40 (1), 214-223.

10. Kalkman, C.J., Peelen, L., \& Moons, K.G. (2009). Behavior and development in children and age all the time of first anesthetic exposure. Anesthesiology, 110, 805-812.

11. Lobov, M., Knyazev, A., \& Ovezov, A. (2010). Perioperative prevention of early cognitive dysfunction in children. Intensive Care Medicine, 36 (Suppl. 2), 276.

12. Davydova, N.S. (2004). Vozmozhnyye kriterii prognoza narusheniy mozgovogo krovoobrashcheniya pri anestezii [Possible criteria for predicting cerebrovascular accidents during anesthesia]. Vestnik intensivnoy terapii
- Bulletin of Intensive Care, 5, 232-234 [in Russian]. 13. Akselrod, B.A. (2012). Monitoring oksygenatsii tkaney: novaya volna $\mathrm{v}$ palitre anesteziologa [Monitoring tissue oxygenation: a new wave in the palette of the anesthetist]. Vestnik intensivnoy terapii - Intensive Care Unit, 1, 8-14 [in Russian].

14. Lubin, A.U., \& Shmigelaky, A.V. (1996). Tserebralnaya oksimetriya [Cerebral oximetry]. Anesteziya i reanimatsiya - Anesthesia and Resuscitation, 2, 85-90 [in Russian].

15. Mchedlishvili, G.I. (1998). Arterial behavior and blood circulation in the brain. N.-Y., 56-57.

16. Reynolds, E.O., Wyatt, J.S., Azzopardi, D., Delpy, D.T., Cady, E.B., Cope, M., \& Wray, S. (1988). New noninvasive methods for assessing brain oxygenation and haemodynamics. Brit. Med. Bull., 1052-1075.

17. Verhagen, E.A., van der Veere, C.N., Groen, H., Dijk, P.H., Hulzebos, C.V., \& Bos, A.F. (2015). Cerebral oxygenation is associated with neurodevelopmental outcome of preterm children at age 2-3 years. Dev. Med. Child Neurol., 57 (5), 449-455. Doi: 10.1111/dmcn.12622 18. Heixensberger, J., Dings, J.T.A., Hanelbeck, B., \& Roosen, K. (1995). Monitoring of cerebral oxygenation by near infrared spectroscopy vs brain tissue PO2 and cerebral perfusion pressure following severe head injury. Procint. Cereb. Hemodyn. Symp., 9, 6. 